\author{
Dr. sc. Duška Šarin \\ Sutkinja Ustavnog suda Republike Hrvatske (2008.-2016.)
}

\title{
JAVNA NARAV I JAVNA KONTROLA DJELOVANJA USTAVNOG SUDA REPUBLIKE HRVATSKE
}

\author{
UDK: 342 . 4 (497. 5) \\ Izvorni znanstveni rad \\ Primljeno: 1. 4. 2016.
}

\begin{abstract}
Demokratsko društvo nije moguće ostvariti, između ostalog, bez otvorene javne rasprave o svim segmentima djelovanja zakonodavne, izvršne i sudbene vlasti, pa samim time i Ustavnog suda Republike Hrvatske. Stoga su javna narav i javna kontrola njegova djelovanja od velikog značaja te, s time u vezi, odnos medija i najšire javnosti prema radu Ustavnog suda. U radu se nastoji općenito ukazati na zadaću ustavnih sudova današnjice, a posebno se bavi javnom naravi aktivnosti ustavnih sudova putem komparativnog prikaza pojedinih ustavnih sudova i Europskog suda za ljudska prava. Podrobno se analizira javna narav aktivnosti Ustavnog suda kroz njegov ustavnopravni položaj i način ostvarenja javnosti djelovanja. Ukazuje se i na probleme u praćenju rada Ustavnog suda od strane zainteresirane javnosti, a posebno su razmotrena moguća rješenja. Analiza dana u radu pokazuje da postoji prostor za poboljšanje javnosti djelovanja Ustavnog suda de lege lata i de lege ferenda.
\end{abstract}

Ključne riječi: javna narav, javnost djelovanja, Ustavni sud, mediji

\section{UVODNO: O ZADAĆI USTAVNIH SUDOVA DANAŠNJICE}

U mnogim europskim postsocijalističkim tranzicijskim državama, kakva je i Republika Hrvatska, upravo je na ustavno sudstvo prebačena zadaća rješavanja raznih ustavnih konflikata, a naročit rezultat tih procesa jest stanje ,juridizacije” u kojem se političke odluke sve više prebacuju na pravnu razinu. Zadaća ustavnih sudova ponekad je usmjerena i na rješavanje tenzija između demokracije i konstucionalizma te se u provedbi te zadaće ustavni sudovi kreću između dvije suprotstavljene koncepcije: koncepcije sudskog aktivizma i koncepcije samoograničenja. ${ }^{1}$

Stoga je funkcionalno ustavno sudstvo jedan od nosilaca demokratske pravne države. Naime, uloga ustavnog sudstva jest osiguranje ostvarivanja ustavom

1 O kontradiktornom odnosu između demokracije i konstitucionalizma te pokretanju novog sagledavanja međusobnog odnosa institucija pojedinih grana državne vlasti više Bačić, P.: „Suvremeni konstitucionalizam i „nova” dioba vlasti“, Zbornik radova Pravnog fakulteta u Splitu, Split, 2009., god. 46, br. 4, str. 747-779. V. i Bačić, A.: „Konstitucionalizam i podjela vlasti u „reaktivnim” ustavima postkomunističkog razdoblja“, Politička misao, Zagreb, 1992., Vol. XXIX., No. 1, str. 43-55. 
Dr. sc. Duška Šarin: Javna narav i javna kontrola djelovanja Ustavnog suda Republike Hrvatske Zbornik radova Pravnog fakulteta u Splitu, god. 53, 4/2016., str. 923.-946.

zajamčenih prava pojedinaca u odnosu na javnu vlast i upućivanje zakonodavne, izvršne i sudbene vlasti u njihove ustavne okvire. Konzekventno, ustavom normirani državni poredak i utvrđena prava zahtijevaju tumačenje odnosno interpretaciju od strane ustavnog suda.

Zato srednje i istočnoeuropski ustavni sudovi, pa tako i hrvatski, predstavljaju vrhovne institucije za rješavanje ustavnih sporova, čime djeluju kao najviši tumači ustava i nositelji tranzicije prema europskim standardima, pri čemu treba biti svjestan da ideju o rješavanju političkih sporova i sukoba primjenom prava nije moguće provesti u potpunosti bez opasnosti da se ,juridizacija politike" ne preokrene u ,politizaciju ustavnog sudstva”. ${ }^{2}$ Primjerice, Ustavni sud Republike Hrvatske imao je potrebu u odluci broj: U-VIIR-4640/2014 od 12. kolovoza 2014. ${ }^{3}$ naglasiti: „Ustavni sud na kraju ističe da nije sudionik političkih rasprava niti je arbitar u rješavanju političkih sporova koji nastaju u hrvatskom društvu".

Uloga je ustavnih sudova da, slijedeći europsko-kontinentalni model ustavnog sudovanja, interpretacijom ustava spriječe samovolju vlasti i razne strukturne aberacije. ${ }^{4}$ Dakle, njihova je zadaća da bdiju nad ustavnošću postupanja države, odnosno radnji koje ona poduzima..$^{5}$ Takvim pristupom funkcija ustavnih sudova služi afirmaciji općih mjerila i smjeru za djelovanje javnih vlasti. ${ }^{6}$

U tom smislu, djelovanje odluka ustavnih sudova u pravilu je za države i društvo neizmjerno važnije i dalekosežnije nego što je to slučaj s konzekvencama koje imaju odluke redovnih sudova. Budući da se kontroli ustavnih sudova podvrgavaju akti

2 Do toga, naime, dolazi zbog općeg smanjivanja povjerenja u političke institucije i transformativne uloge ustavnih sudova u tranzicijskim državama. Usp. Omejec, J.: „Novi europski tranzicijski ustavi i transformativna uloga ustavnih sudova“, u: Dvadeseta obljetnica Ustava Republike Hrvatske, HAZU, Zagreb, 2011., str. 61-85; Barić, S.: „Organski zakoni i Ustavni sud Republike Hrvatske u usporednopravnoj perspektivi“, u: Liber amicorum in honorem Jadranko Crnić (1928. - 2008.), Novi informator, Zagreb, 2009., str. 251-283.

3 V. odluku Ustavnog suda broj: U-VIIR-4640/2014 od 12. kolovoza 2014. (Narodne novine broj 104/14. i www.usud.hr), donesenu u postupku pokrenutom na zahtjev Hrvatskog sabora radi utvrđenja je li referendumsko pitanje u skladu s Ustavom Republike Hrvatske (Narodne novine broj 56/90., 135/97., 113/00., 28/01., 76/10. i 5/14.) i jesu li ispunjene pretpostavke iz članka 87. stavaka 1. do 3. Ustava Republike Hrvatske za raspisivanje referenduma.

4 O europsko-kontinentalnom ili Kelsenovom modelu ustavnog sudovanja v. Šarin, D.: „Ustavni sud Republike Hrvatske kao institucionalni zaštitnik ljudskih prava i temeljnih sloboda“, Zbornik radova Pravnog fakulteta u Splitu, Split, 2015., god. 52, br. 3, str. 758-759 i dalje.

5 Usp. Geissler, T.: „Predgovor“, Izbor odluka Ustavnog suda Savezne Republike Njemačke, Zaklada Konrad Adenauer, Zelina, 2015., str. 11.

6 Općenito o tome v. Crnić, J., Filipović, N. (ur.): Ustavni sud u zaštiti ljudskih prava: interpretativna uloga Ustavnog suda, Biblioteka Pravo 24, Zagreb, Hrvatski pravni centar, Organizator, Hrvatski institut za ljudska prava Novi Vinodolski, Hans Seidel Stiftung, Deutsche Stiftung für internationale rechtliche Zusammenarbeit e.V., 2000. Detaljnije, Zierlein, K. G.: „Uloga ustavnih sudova pri interpretaciji pravnih normi“", u: Ustavni sud u zaštiti ljudskih prava: interpretativna uloga Ustavnog suda, Organizator, Zagreb, 2000., str. 327-346; Goldsworthy, J.: Constitutional Interpretation, The Oxford Handbook of Comparative Constitutional Law, 2013., str. 689-715. 
zakonodavne, izvršne i sudbene vlasti, odluke ustavnih sudova odnosno postupci u kojima se one donose predstavljaju predmet iznimne pažnje opće javnosti.

Pri tome je od velikog značaja da djelovanje ustavnih sudova bude što transparentnije i u dovoljnoj mjeri i na adekvatan način (objektivno, stručno i sl.) predstavljeno u medijima, kako bi i najšira javnost znala što je uloga i funkcija ustavnih sudova. Naime, mediji imaju odlučujuću ulogu u tome da javnosti odnosno potencijalnim podnositeljima ustavnih tužbi i prijedloga za pokretanje drugih ustavnosudskih postupaka objasne odluke ustavnih sudova i dovedu do što boljeg razumijevanja načina na koji ustavni sudovi funkcioniraju, pa tako i Ustavni sud Republike Hrvatske (u daljnjem tekstu: Ustavni sud).

Iako se javnost djelovanja Ustavnog suda očituje kroz javnost naravi ustavnosudskih rasprava i kroz javnost naravi donošenja ustavnosudskih odluka, praćenje rada Ustavnog suda od strane zainteresirane javnosti još uvijek nije na zadovoljavajućoj razini.

Stoga je cilj ovog rada pojasniti ne samo ustavnopravni položaj, odnosno ulogu i rad Ustavnog suda, već i s aspekta normativnog uređenja i znanstvenog određenja ukazati na bit i stvarni domašaj primjene načela javnosti u radu Ustavnog suda. Dosljedno tome, u radu se problematizira odnos medija i uopće najšire javnosti prema djelovanju i odlukama Ustavnog suda da bi se ukazalo na to ima li odnosno koji su problemi glede objektivnog i kvalitetnog izvještavanju o radu Ustavnog suda, što se poduzima da bi se u javnosti afirmirao njegov rad te na koji način je sam Ustavni sud otvoren prema medijima i javnosti uopće. Konačno, u radu su ponuđena moguća rješenja de lege lata i de lege ferenda, koristeći komparativna iskustva drugih ustavnih sudova te Europskog suda za ljudska prava u Strasbourgu (u daljnjem tekstu: Europski sud).

\section{JAVNA NARAV AKTIVNOSTI USTAVNIH SUDOVA - KOMPARATIVNI PRIKAZ}

Javnost djelovanja ustavnih sudova predstavlja oblik kontrole ili nadzora nad nepristranošću i pravovaljanošću postupka odlučivanja. Iako je javna narav aktivnosti ustavnih sudova ponegdje deklarirana već u samim ustavima, najčešće je propisana u zakonima o ustavim sudovima. Javnost djelovanja ustavnih sudova ostvaruje se na različite načine. Međutim, kako to navode Harutyunyan i Mavčić, ${ }^{7}$

\footnotetext{
Harutyunyan, G., Mavčič, A.: Constitutional Review and its Development in the Modern World (A Comparative Constitutional Analysis), Electronic Book, Yerevan-Ljubljana, 1999., str. 134. i dalje, Ustavni sud Republike Armenije, www.concourt.am/armenian/library/cclibrary/1999/009.doc., pristupljeno 17. ožujka 2016.
} 
u ustavnom sudstvu prevladavaju načela javne naravi ustavnosudskih rasprava (public nature of court hearings) i javne naravi donošenja ustavnosudskih odluka (public nature of delivering decisions).

Iznimke su najčešće propisane mjerodavnim zakonima, a odnose se na tzv. zakonske rezerve (legal reservations). Dakle, isključenje javnosti rezervirano je za zaštitu interesa maloljetnika ili javnog interesa, najčešće javnog morala.

Budući da su značenje i utjecaj njemačkog Saveznog ustavnog suda izašli izvan nacionalnih okvira jer je njegova jurisprudencija, zahvaljujući pravnoj i institucionalnoj tradiciji duljoj od 60 godina, odavno postala stalan izvor „,načela, općih pravila i metoda ustavne interpretacije u postupcima zaštite temeljnih prava građana i očuvanja objektivnog nacionalnog ustavnopravnog poretka" te je stoga vrlo često i smjernica ustavnim sudovima drugih država za njihovo djelovanje, pa tako i hrvatskom Ustavnom sudu, važno je poznavati i javnu narav aktivnosti toga suda. ${ }^{8}$

Iako njemački Savezni ustavni sud, u praksi, samo izuzetno odlučuje na osnovi javne rasprave, i to u okviru onih postupaka o kojima postoje kontroverzne diskusije u javnosti, na njima je dopušteno fotografiranje, filmsko i tonsko snimanje do završetka utvrđivanja prisutnosti sudaca u postupku. ${ }^{9}$ Snimanja su dozvoljena i prilikom javnog objavljivanja odluka koje Savezni ustavni sud donosi nakon provedene javne rasprave.

Ipak, javnost djelovanja Saveznog ustavnog suda osigurana je i u predmetima u kojima se ne održavaju javne rasprave kroz Službu za medije tog suda koja ima centralnu ulogu kada je riječ o kontaktima i komunikaciji s medijima. Naime, ta služba, kao svojevrstan glasnogovornik Saveznog ustavnog suda, priprema odluke suda za objavljivanje te po potrebi osigurava kontakte sa sucima koji, ipak, predstavljaju iznimku, ${ }^{10}$ jer davanje odgovora na pitanja koja se odnose na sadržaj pojedine odluke u osnovi je zadatak Službe za medije. Pored toga, važan instrument koji ta služba u odnosu s medijima koristi jesu i priopćenja za tisak koja se objavljuju i na internetskim stranicama suda. To su, prije svega, najave javnih rasprava, najave objavljivanja presuda, kao i prezentacija odluka Saveznog ustavnog suda. Spomenimo još da priopćenja za tisak predstavljaju i najvažniji

8 O značaju i utjecaju njemačkog Saveznog ustavnog suda na praksu Ustavnog suda v. Omejec, J.: „Jurisprudencija njemačkog Saveznog ustavnog suda i hrvatsko ustavno sudstvo“, Izbor odluka Ustavnog suda Savezne Republike Njemačke, Zaklada Konrad Adenauer, Zelina, 2015., str. 15. - 26.

9 Na taj način postoji mogućnost da se građani još prije objavljivanja presude, do koje dolazi najčešće tek mjesecima kasnije, uz pomoć medija pripreme na mogući ishod postupka kao i da se prevenira eventualna kritika. V. Hömig, D.: „Ustavni sudovi i mediji u Saveznoj Republici Njemačkoj“, str. 1-16, referat za konferenciju Ustavni sud $i$ mediji, Republika Srbija, Kladovo, 3. do 5. rujna 2015. (arhiva Ustavnog suda).

10 Naime, i suci njemačkog Saveznog ustavnog suda postupaju sukladno općevažećem načelu da suci govore kroz svoje presude, a ne o njima. 
instrument u nastojanju da se Savezni ustavni sud i njegova jurisprudencija uz pomoć medija približe građanima kako bi javnost bila u stanju prepoznati koristi ustavnog sudstva za državu i društvo i te koristi cijeniti. Prihvaćenost i popularnost Saveznog ustavnog suda u Republici Njemačkoj pokazuju da su se trud i resursi uloženi u to višestruko isplatili. ${ }^{11}$

Kada se govori o javnoj naravi aktivnosti ustavnih sudova, valja spomenuti i Ustavni sud Republike Srbije upravo zbog određenih problema koje je imao s javnošću svojih sjednica. Naime, ranijim poslovnicima o njegovu radu, za razliku od zakona, bilo je određeno da i na sjednicama (redovnim), a ne samo na javnoj raspravi, mogu biti nazočni predstavnici tiska, radija i televizije. To je konkretno značilo da su suci na svim sjednicama, ${ }^{12}$ uključujući i faze vijećanja i glasovanja o odluci, bili izloženi tzv. općoj javnosti. ${ }^{13}$

Međutim, Poslovnik o radu Ustavnog suda (Republike Srbije) iz 2013. godine ${ }^{14}$ usklađen je sa Zakonom o Ustavnom sudu te se javnost rada Ustavnog suda Republike Srbije ostvaruje prisustvom akreditiranih predstavnika sredstava javnog informiranja samo na javnoj raspravi. ${ }^{15}$ Održavanje javne rasprave uvijek je obvezatno u postupku odlučivanja o izbornim sporovima i postupku za zabranu rada političke stranke, sindikalne organizacije, udruženja građana ili vjerske zajednice, a u pravilu javna rasprava uvijek se održava i u postupku apstraktne ustavnosudske kontrole. ${ }^{16}$ Pored toga, javnost rada ostvaruje se i objavljivanjem odluka u „Službenom glasniku Republike Srbije”, izdavanjem biltena odluka suda, objavljivanjem na internetskim stranicama dnevnih redova sjednica, vremena

11 Više o Službi za medije Saveznog ustavnog suda v. Hömig, op. cit. u bilj. 9, str. 7-15.

12 Dakle, i sjednicama na kojima se odlučivalo o konkretnoj ustavnosudskoj kontroli.

13 O problemima Ustavnog suda Republike Srbije vezanima uz javnost njegovih sjednica v. Draškić, M.: Javnost sednica Ustavnog suda Srbije - kako je bilo i kako je sada?, str. 1-11, Fondacija Centar za javno pravo, http://www.fcjp.ba/templates/ja_avian_ii_d/images/green/Marija_Draskic2.pdf., pristupljeno 4. travnja 2016. Usp. Slijepčević, D. B.: Javnost rada u praksi Ustavnog suda Srbije, str. 1-13, Fondacija Centar za javno pravo, http://www.fcjp.ba/templates/ja_avian_ii_d/images/green/Dragisa_B_Slijepcevic. pdf., pristupljeno 4. travnja 2016. 103/13.).

14 V. članak 29. stavak 1. Poslovnika o radu Ustavnog suda (,Službeni glasnik Republike Srbije” broj

15 Naime, člankom 3. stavcima 1. i 2. Zakona o Ustavnom sudu („Službeni glasnik Republike Srbije” broj 109/07., 99/11., 18/13., 40/15. i 103/15.) određeno je da je rad Ustavnog suda Republike Srbije javan, a javnost se osigurava, uz održavanje javne rasprave i rasprave o postupku pred Ustavnim sudom (dakle, postupak apstraktne ustavnosudske kontrole), objavljivanjem odluka, objavljivanjem izvještaja sa sjednica na internetskim stranicama, davanjem priopćenja sredstvima javnog informiranja, održavanjem konferencija za medije i na drugi način.

16 Ustavni sud Republike Srbije može odlučiti da ne održi javnu raspravu u postupku ocjenjivanja ustavnosti i zakonitosti ako ocijeni da je u tijeku postupka stvar dovoljno razjašnjena i da, na osnovi pribavljenih dokaza, može odlučiti i bez održavanja javne rasprave. Tako može odlučiti i u slučaju ako je o istoj stvari već odlučeno, a nisu dani novi razlozi za drugačije odlučivanje u toj stvari, kao i ako postoje uvjeti za obustavu postupka. O javnoj raspravi pred Ustavnim sudom Republike Srbije v. članke 37. - 41. Zakona o Ustavnom sudu, op. cit. u bilj. 15 i članke 48. - 52. Poslovnika o radu Ustavnog suda, op. cit. u bilj. 14. 
Dr. sc. Duška Šarin: Javna narav i javna kontrola djelovanja Ustavnog suda Republike Hrvatske Zbornik radova Pravnog fakulteta u Splitu, god. 53, 4/2016., str. 923.-946.

održavanja javne rasprave, odluka i ustavnosudske prakse, kao i najvažnijih podataka vezanih za rad suda. Najzad, javnost djelovanja osigurana je i kroz dostavljanje službenih obavijesti sredstvima javnog priopćavanja te održavanje konferencija za predstavnike sredstava javnog priopćavanja.

Zakonom o Ustavnom sudu propisane su i iznimke od načela javne naravi aktivnosti Ustavnog suda Republike Srbije na način da se javnost može isključiti samo radi zaštite interesa nacionalne sigurnosti, javnog reda i morala u demokratskom društvu, te radi zaštite interesa maloljetnika ili privatnosti sudionika u postupku. Međutim, isključenje javnosti ne odnosi se na sudionike u postupku, njihove punomoćnike i predstavnike stručne javnosti. ${ }^{17}$

S obzirom na to da je Republika Hrvatska, kao i ostale članice Vijeća Europe, pod jurisdikcijom Europskog suda, ${ }^{18}$ skreće se pozornost i na javnu narav njegove aktivnosti. ${ }^{19}$ I sam Europski sud smatra da je za njegov efikasan rad od izuzetnog značaja da javnost u državama članica, kao i oni koji su u tim državama odgovorni za primjenu i provođenje sudske prakse, poznaju jurisprudenciju Europskog suda, ali i da razumiju njegove presude. Stoga je jasno da mediji imaju odlučujuću ulogu u tome da odgovornima i javnosti odnosno potencijalnim podnositeljima zahtjeva pred Europskim sudom, kao i pred nacionalnim sudovima, objasne njegove presude i dovedu do boljeg razumijevanja načina na koji Europski sud funkcionira.

U tom smislu Europski sud ima posebnu službu za odnose s medijima koja je isključivo nadležna za informiranje medija, te sastavlja izvještaje za tisak koji se automatski objavljuju na twitteru, organizira godišnje konferencije za tisak, brifinge za dopisnike iz Strasbourga, a za grupe novinara iz pojedinih zemalja i dvodnevne seminare u okviru kojih postoji mogućnost prisustvovanja usmenoj

17 Spomenimo još da sudac ne može javno iznositi svoje mišljenje o pitanju koje je predmet spora pred Ustavnim sudom Republike Srbije. V. članak 3. stavke 3. - 5. Zakona o Ustavnom sudu, op. cit. u bilj. 15 .

18 Europski sud uspostavljen je Konvencijom za zaštitu ljudskih prava i temeljnih sloboda (u daljnjem tekstu: Konvencija), odnosno Protokolom broj 11. Osnovano je, dakle, međunarodno sudsko tijelo koje ima ovlast donošenja presuda protiv država ugovornica ako one krše pravila Konvencije. Naime, člankom 46. stavkom 1. Konvencije propisano je da se visoke ,ugovorne stranke obvezuju da će se podvrgnuti konačnoj presudi Suda u svakom sporu u kojem su stranke”. Dosljedno tome, sve zemlje koje su ratificirale Konvenciju, pa tako i Republika Hrvatska, dužne su priznati obvezatnost presude Europskog suda u predmetu u kojem su bile stranke. Valja napomenuti da je Europski sud vrlo rano utvrdio svoju zadaću u primjeni Konvencije, te je u predmetu Irska protiv Ujedinjenog Kraljevstva (1978.) izrazio stajalište da presude Europskog suda zapravo služe ne samo rješavanju onih slučajeva koji su podneseni pred Europski sud, već, puno šire, razlaganju, očuvanju i razvijanju pravila što ih je ustanovila Konvencija. Europski sud, dakle, postao je kreator „europskih ustavnih standarda”, koje na nacionalnim razinama trebaju provoditi nacionalna tijela, osobito sudovi. Usp. Häberle, P.: „,Role and Impact of Constitutional Courts in a Comparative Perspective“, The Future of the European Judical System in a Comparative Perspective, Nomos, Baden-Baden, 2006.

19 Smatramo, naime, da bi ona bila dobra smjernica za ustavne sudove država ugovornica i zbog činjenice da su ustavni sudovi institucije koje po svome položaju unutar nacionalnog ustavnog poretka vrše funkciju paralelnu onoj koju unutar Vijeća Europe obavlja Europski sud. 
$\operatorname{raspravi~}^{20}$ i razgovora sa sucima i pravnim suradnicima koji nisu namijenjeni za objavljivanje. Pored toga postoji i mogućnost snimanja objavljivanja presuda, a dijelovi video-zapisa s usmenih rasprava stavljaju se na raspolaganje TV-kanalima, dok se webcastovi cijelih usmenih rasprava postavljaju nakon završetka tih rasprava na internetske stranice Europskog suda.

Valja napomenuti da se u centralne zadatke službe za odnose s medijima ubrajaju i objavljivanja posebnih izvještaja za medije koji se odnose na postupke čiji se predmet odnosi na veliki broj podnositelja ili potencijalnih podnositelja. Ostale odluke, koje se odnose na velik broj podnositelja i u kojima Europski sud uvijek objavljuje posebna izvješća za medije takozvane su pilot presude zbog toga što se u njima ukazuje na strukturalni problem u zemlji o kojoj je riječ, a koji onda i predstavlja razlog za veliki broj sličnih zahtjeva pred Europskim sudom. Na kraju valja spomenuti da način na koji će neka presuda Europskog suda biti prihvaćena u javnosti u pojedinoj državi članici Vijeća Europe ovisi i o tome kakvo shvaćanje državnog suvereniteta prevladava, kakav je stav u odnosu na Europu odnosno međunarodno pravo, te o dotadašnjem diskursu u vezi s konkretnim pravnim pitanjem o kojem je riječ. ${ }^{21}$

\section{JAVNA NARAV AKTIVNOSTI USTAVNOG SUDA REPUBLIKE HRVATSKE}

\subsection{Ustavni sud Republike Hrvatske - ustavnopravni položaj}

Ustavom Republike Hrvatske (u daljnjem tekstu: Ustav) ${ }^{22}$ Ustavni sud ustrojen je, uz zakonodavnu, izvršnu i sudbenu vlast, kao, uvjetno rečeno, ,četvrta vlast” ili „međuvlast”. Međutim, Ustavni sud nije iznad njih, koje su po načelu diobe

20 Naime, sukladno Poslovniku Suda (www.echr.coe.int, pristupljeno 4. travnja 2016.) postupak pred Europskim sudom jest javan te su rasprave vijeća javne, osim ako vijeće, samo u iznimnim okolnostima, odluči drugačije, bilo na vlastitu inicijativu, bilo na zahtjev stranke ili neke druge zainteresirane osobe. Mediji i javnost mogu biti isključeni sa cijele rasprave ili sa dijela rasprave u interesu morala, javnog reda ili nacionalne sigurnosti u demokratskom društvu, kad to zahtijevaju interesi maloljetnika ili zaštita privatnog života stranaka, ili u mjeri koja je nužno potrebna, po mišljenju vijeća, u posebnim okolnostima kad bi javnost bila na štetu interesa pravde.

21 Usp. Salomon, N.: „Odnosi s medijima Europskog suda za ljudska prava“, str. 1-9, referat za konferenciju Ustavni sud i mediji, Republika Srbija, Kladovo, 3. do 5. rujna 2015. (arhiva Ustavnog suda).

22 Budući da nadležni odbor Hrvatskog sabora još uvijek nije objavio novi pročišćeni tekst Ustava izrađen u skladu s izvješćem Ustavnog suda broj: U-X-1435/2011 od 23. ožujka 2011., u radu se za označavanje članaka Ustava koriste izvornici ustavnih tekstova (Narodne novine broj 56/90., 135/97., 113/00., 28/01., 76/10. i 5/14.). 
vlasti određene kao samostalne i neovisne..$^{23}$ Dosljedno tome, Ustavni sud je već u rješenju broj: U-I-143/1995 od 15. veljače 1995., donesenom u postupku ocjene suglasnosti s Ustavom odredbe Zakona o Državnom sudbenom vijeću, ${ }^{24}$ naveo:

„(...) Ustavnu odredbu o trodiobi vlasti ne treba mehanički shvatiti i tumačiti. Svrha primjene načela o diobi vlasti jest sprječavanje koncentracije ovlaštenja i političke moći (samo) unutar jednog organa (državne vlasti). Ostvarenju te svrhe u suvremenim ustavnim sistemima različito se prilazi, a svodi se na povjeravanje osnovnih državnih funkcija različitim državnim organima, pri čemu su odnosi između državnih organa koji obavljaju različite državne funkcije vrlo različito uspostavljeni u pojedinim državama.

U našem sistemu trodiobe vlasti one se uzajamno nadziru i ograničavaju, ali se i prožimaju.

Kada bi doista bila riječ o trodiobi vlasti na način kako je shvaća predlagatelj, onda bi teško mogao biti objašnjiv položaj Ustavnog suda Republike Hrvatske koji nije svrstan niti u jednu od triju vlasti, a nadzire sve tri državne vlasti u pogledu ustavnosti i zakonitosti, dakako samo u nadležnostima utvrđenim Ustavom. Ustavni sud hijerarhijski ipak nije iznad njih a niti je njihov dio. (...)"25

Položaj Ustavnog suda, kao ustavnog tijela sui generis,${ }^{26}$ određen je i njegovom osnovnom zadaćom. Naime, Ustavni sud kao najviše ustavno tijelo za osiguranje vladavine prava i zaštitu ljudskih prava u Republici Hrvatskoj, jamči poštovanje i primjenu Ustava. Između ostaloga, ovlašten je uklanjati iz pravnog poretka neustavne zakone Hrvatskog sabora, uredbe i druge propise predsjednika Republike Hrvatske i Vlade Republike Hrvatske (u daljnjem tekstu: Vlada), pravilnike, naredbe i naputke ministara, te propise svih drugih tijela državne vlasti i pravnih osoba s javnim ovlastima, ali i presude redovnih i specijaliziranih sudova, uključujući

23 O načelu diobe vlasti v. Sokol, S.: „Načelo diobe ili ograničenja vlasti“, Politička misao, Zagreb, 1992., Vol. XXIX, No. 1, str. 17; Bačić, A.: „Ustav Republike Hrvatske i problematika podjele vlasti“, Zakonitost, Zagreb, 1991., Vol. 45, br. 2, str. 160. Usp. i Sarin, D.: „Načelo diobe vlasti i njegova primjena u hrvatskom ustavnom uređenju“, Vladavina prava, Zagreb, 1999., god. III., br. 6, str. 157-170; Šrin, D.: „Položaj Ustavnog suda Republike Hrvatske s motrišta diobe vlasti i ustavne garancije njegove neovisnosti“" Zbornik Pravnog fakulteta u Zagrebu, Zagreb, 2012., Vol. 62, br. 5-6, str. 1379-1383.

24 Zakon o Državnom sudbenom vijeću (Narodne novine, broj 58/93.).

${ }_{25}$ V. rješenje Ustavnog suda broj: U-I-143/1995 od 15. veljače 1995. (Narodne novine broj 88/09. i 18/95. - ispravak i www.usud.hr).

${ }^{26}$ Usp. Sokol, S.: „Odnos Ustavnog suda i tijela sudbene vlasti“, Zbornik Pravnog fakulteta u Zagrebu, Zagreb, 2000., Vol. 50, br. 1-2, str. 55-64. 
i presude Vrhovnog suda Republike Hrvatske (u daljnjem tekstu: Vrhovni sud) kao najvišeg suda u zemlji, ako se njima krše Ustavom zajamčena ljudska prava i temeljne slobode. Nadalje, Ustavni sud prati ostvarivanje ustavnosti i zakonitosti te o uočenim pojavama neustavnosti i nezakonitosti izvješćuje Hrvatski sabor. Rješava sukob nadležnosti između tijela zakonodavne, izvršne i sudbene vlasti. Odlučuje, u skladu s Ustavom, o odgovornosti predsjednika Republike, nadzire ustavnost programa i djelovanja političkih stranaka i može, u skladu s Ustavom, zabraniti njihov rad, a nadzire i ustavnost i zakonitost izbora i državnog referenduma te rješava izborne sporove koji nisu u djelokrugu sudova. ${ }^{27}$

Premda se, dosadašnjim promjenama Ustava, djelokrug poslova Ustavnog suda stalno širio, apstraktna ustavnosudska kontrola zakona i drugih propisa, te zaštita ustavnih prava i temeljnih sloboda kroz postupak individualne ustavne kontrole, ostale su njegove najvažnije i najutjecajnije nadležnosti. ${ }^{28}$

Stoga su upravo odluke donesene u tim postupcima i najviše podvrgnute kontroli javnosti jer izazivaju najveće zanimanje medija i javnosti uopće.

Skreće se pozornost na to da, osim što se ustavnopravni položaj Ustavnog suda izražava u nadležnostima koje su mu Ustavom dane, odnosno u pravnim učincima ustavnosudskih odluka i rješenja koja neposredno djeluju u područjima zakonodavne, izvršne i sudbene vlasti, sve odluke i rješenja Ustavnog suda obvezatna su i dužne su ih poštovati sve fizičke i pravne osobe, a sva tijela državne vlasti i lokalne i područne (regionalne) samouprave dužna su ih provoditi u okviru svoga ustavnog i zakonskog djelokruga. Štoviše, provedbu odluka i rješenja Ustavnog suda osigurava Vlada preko tijela državne uprave. ${ }^{29}$

\subsection{Javnost djelovanja Ustavnog suda Republike Hrvatske}

Ustavni zakon o Ustavnom sudu Republike Hrvatske (u daljnjem tekstu: Ustavni zakon) izrijekom propisuje da je djelovanje Ustavnog suda javno, ${ }^{30}$ a način ostvarenja javnosti djelovanja propisan je Poslovnikom Ustavnog suda Republike Hrvatske $^{31}$ (u daljnjem tekstu: Poslovnik). To se odnosi i na javnost naravi ustavnosudskih rasprava i na javnost naravi donošenja ustavnosudskih odluka. ${ }^{32}$

\footnotetext{
27 Nadležnosti Ustavnog suda određene su člankom 125. Ustava. 1388.

28 Više o promjenama nadležnosti Ustavnog suda v. Šarin, „Položaj ...“, op. cit. u bilj. 23, str. 1385-

29 O provedbi odluka odnosno rješenja Ustavnog suda v. članak 31. Ustavnog zakona o Ustavnom sudu Republike Hrvatske (Narodne novine broj 99/99. i 29/02.).

30 V. članak 3. Ustavnog zakona.

31 V. članak 4. Poslovnika Ustavnog suda Republike Hrvatske (Narodne novine broj 181/03., 16/06., 30/08., 123/09., 63/10., 121/10., 19/13., 37/14. i 2/15.).

32 Pojam „ustavnosudska odluka“ obuhvaća, uz odluke, i rješenja te izvješća Ustavnog suda.
} 
Ustavni sud na sjednici može zaključiti da će o biti stvari odlučiti na temelju javne rasprave, koju zakazuje predsjednik Ustavnog suda. Na javnu raspravu pozivaju se sudionici u postupku i predstavnici državnih tijela, tijela lokalne i područne (regionalne) samouprave i udruga, kao i one osobe čije je sudjelovanje na javnoj raspravi potrebno. Izostanak pozvanih sudionika u postupku i drugih pozvanih osoba ne sprečava Ustavni sud da nastavi postupak i donese odluku, ako ocijeni da za to postoje uvjeti. No, u opravdanim slučajevima Ustavni sud može odgoditi javnu raspravu i zakazati novu. ${ }^{33}$

Javnu raspravu vodi predsjednik Ustavnog suda, a o činjeničnom i pravnom stanju u predmetu izvješćuje sudac izvjestitelj. O samom tijeku javne rasprave zapisnik vodi savjetnik Ustavnog suda koji je sa sucem izvjestiteljem surađivao u obradi predmeta. ${ }^{34}$ Javna se rasprava snima, ako predsjednik Ustavnog suda ne odluči drukčije, a ta se snimka prilaže zapisniku. ${ }^{35}$ Najzad, kada Ustavni sud smatra da je predmet raspravljen u mjeri da može donijeti odluku, predsjednik Ustavnog suda priopćuje da je rasprava zaključena. ${ }^{36}$

Na javnim raspravama, ali i na sjednicama Ustavnog suda na kojima se donose odluke te na drugim skupovima u Ustavnom sudu mogu biti nazočni predstavnici tiska i drugih sredstava priopćavanja. ${ }^{37}$ Valja napomenuti da na sjednicama Ustavnog suda te javnim, ali i savjetodavnim raspravama u Ustavnom sudu ${ }^{38}$ mogu biti nazočni samo akreditirani novinari koji potpišu izjavu o čuvanju tajnosti osobnih podataka o fizičkim osobama i odgovarajućih podataka o pravnim osobama i drugim strankama o kojima se raspravljalo, odnosno koji su navedeni u nacrtima odluka i rješenja izrađenima u povodu ustavnih tužbi koji su bili na dnevnom redu sjednice Ustavnog suda, a u kojima nisu primijenjena pravila o anonimizaciji. ${ }^{39}$

33 Usp. članak 50. Ustavnog zakona.

${ }_{34}$ Taj savjetnik i potpisuje zapisnik zajedno s predsjednikom Ustavnog suda, kako je to određeno člankom 51. stavkom 3. Ustavnog zakona.

35 Ustavnim zakonom predviđena je čak i mogućnosti stenografiranja javne rasprave (v. članak 51. stavak 2.).

36 V. članak 52. Ustavnog zakona.

37 Mogućnost prisutnosti predstavnika tiska i drugih sredstava priopćavanja određen je člankom 47. stavkom 3. Ustavnog zakona.

38 Naime, Ustavni sud održava savjetodavnu raspravu ako ocijeni da je prije odlučivanja o biti stvari potrebna rasprava sa sudionicima u postupku, državnim tijelima, tijelima lokalne i područne (regionalne) samouprave, udrugama, znanstvenicima i drugim stručnjacima, sukladno članku 49. Ustavnog zakona i članku 32. Poslovnika.

39 Obveza čuvanja tajnosti podataka traje do objave odluke (rješenja) o ustavnoj tužbi na internetskoj stanici Ustavnog suda, a najkasnije 30 dana od dana donošenja ako do isteka tog roka ne bude objavljena, sukladno članku 61. Poslovnika. 
Dr. sc. Duška Šarin: Javna narav i javna kontrola djelovanja Ustavnog suda Republike Hrvatske Zbornik radova Pravnog fakulteta u Splitu, god. 53, 4/2016., str. 923.-946.

Za televizijski i radio-prijenos iz Ustavnog suda potrebna je dozvola predsjednika Ustavnog suda. ${ }^{40}$

Sukladno spomenutom načelu zakonskih rezervi, ako postoje razlozi za isključenje javnosti u postupku sudac Ustavnog suda koji je izvjestitelj u dotičnom predmetu to navodi u izvješću pripremljenom za sjednicu Ustavnog suda. ${ }^{41}$

Usporedbe radi, odluke redovnih i specijaliziranih sudova, uključujući i Vrhovni sud, u povodu pravnih lijekova (žalbe, revizije i slično) donose se na sjednicama vijeća koje nisu otvorene za javnost. Isto tako, iako načelo javnosti omogućuje predstavnicima sredstava javnog priopćavanja prisustvovanje svim raspravama redovnih i specijaliziranih sudova, ${ }^{42}$ uključujući i objavljivanje presude, vijećanje i glasovanje o presudi je tajno. ${ }^{43}$

Javnost djelovanja Ustavnog suda, osim navedenog, ostvaruje se:

1. objavom ustavnosudskih odluka, rješenja i izvješća u Narodnim novinama, službenom glasilu Republike Hrvatske, ${ }^{44}$

40 Međutim, uobičajena je praksa da se i bez posebne dozvole predsjednika Ustavnog suda, utvrđene člankom 47. stavkom 4. Ustavnog zakona, snima samo početak sjednice Ustavnog suda, a dozvola se traži za snimanje cijele sjednice. Spomenimo još da se dozvola najčešće traži za one sjednice na kojima se odlučuje o predmetima koji se odnose na veći broj osoba pa stoga postoji i veliki interes javnosti. Primjerice, predmet broj: U-IP-3820/2009 i dr. u kojem je Ustavni sud ocjenjivao ustavnost Zakona o posebnom porezu na plaće, mirovine i druge primitke (Narodne novine broj 94/09.) tzv. „krizni porez”, predmet broj: U-VIIR-4696/2010 u kojem je Ustavni sud ocjenjivao postojanje ustavnih pretpostavki za raspisivanje državnog referenduma, predmet broj: U-II-1118/2013 i dr. u kojem je Ustavni sud ocjenjivao suglasnost Odluke o uvođenju, praćenju i vrednovanju provedbe Kurikuluma zdravstvenog odgoja $\mathrm{u}$ osnovnim i srednjim školama (Narodne novine broj 17/13.).

41 Obveza navođenja razloga za isključenje javnosti određena je člankom 21. Ustavnog zakona.

42 Naime, ,u doktrini se načelo javnosti definira kao zahtjev da se svakome - dakle, neograničenom broju osoba koje unaprijed nisu individualno određene - osigura nesmetana mogućnost prisustvovanja raspravljanju pred sudom”. Dika, M.: „Načelo javnosti u parničnom postupku - prilog pokušajima opravdanja i reafirmacije instituta“, Zbornik Pravnog fakulteta Sveučilišta u Rijeci, Rijeka, 2008., god. 29, br. 1, str. 1-26.

43 Sukladno članku 117. Ustava, sudske su rasprave javne i presude se izriču javno u ime Republike Hrvatske. Međutim, kao i kod ustavnosudskih rasprava, javnost se ipak može iznimno isključiti iz cijele rasprave ili njezina dijela zbog razloga koji su nužni u demokratskom društvu radi interesa morala, javnog reda ili državne sigurnosti, osobito ako se sudi maloljetnicima, ili radi zaštite privatnog života stranaka, ili u bračnim sporovima i postupcima u vezi sa skrbništvom i posvojenjem, ili radi čuvanja vojne, službene ili poslovne tajne i zaštite sigurnosti i obrane Republike Hrvatske. No, takvo isključenje javnosti može biti samo u opsegu koji je po mišljenju suda bezuvjetno potreban u posebnim okolnostima u kojima bi javnost mogla biti štetna za interese pravde. Više o odnosu sudstva prema javnosti i medijima Crnić, I.: Neovisnost sudstva, Vrhovni sud Republike Hrvatske, http://www.vsrh.hr/easyweb.asp?pcpid=698, pristupljeno 9. svibnja 2016.

${ }_{44}$ Objavljuju se odluke i rješenja Ustavnog suda, doneseni u postupku ocjene suglasnosti zakona s Ustavnom, odnosno suglasnosti drugih propisa s Ustavom i zakonom, te odluke i rješenja doneseni u ustavnosudskim postupcima za zaštitu ljudskih prava i temeljnih sloboda zajamčenih Ustavom. Međutim, u slučaju da više odluka ili rješenja počiva na istoj pravnoj osnovi i istom ili sličnom činjeničnom stanju objavit će se samo jedna odluka, odnosno rješenje. O objavi ostalih akata Ustavnog suda odlučuje sjednica Ustavnog suda. V. članak 29. Ustavnog zakona. 
Dr. sc. Duška Šarin: Javna narav i javna kontrola djelovanja Ustavnog suda Republike Hrvatske Zbornik radova Pravnog fakulteta u Splitu, god. 53, 4/2016., str. 923.-946.

2. izdavanjem zbirki odluka, rješenja i izvješća („Izbor odluka Ustavnog suda Republike Hrvatske", službena publikacija Ustavnog suda koja izlazi godišnje, počevši od 2010. godine, s time da je prvi broj obuhvatio period od 1996. - 2009.), ${ }^{45}$

3. dostavom službenih priopćenja sredstvima javnog priopćavanja, ${ }^{46}$

4. održavanjem konferencija za tisak i druga sredstva javnog priopćavanja ${ }^{47} \mathrm{i}$

5. objavom ustavnosudske prakse, te važnijih podataka na službenim internetskim stranicama Ustavnog suda (www.usud.hr). ${ }^{48}$

$\mathrm{Na}$ službenim internetskim stranicama Ustavnog suda mogu se pronaći ustavnosudske odluke, rješenja i izvješća doneseni od 1995. godine, a odabrani prema nekoliko mjerila: prema važnosti za širu javnost, prema broju adresata na koje se odnose i prema vrstama ustavnosudskih postupaka. Zbirka ustavnosudske prakse na službenim internetskim stranicama Ustavnog suda kontinuirano se i trajno ažurira novim ustavnosudskim aktima. ${ }^{49}$

Osim toga, od 1992. sažeci najvažnijih odluka Ustavnog suda objavljuju se u Bulletin on Constitutional Case Law Venecijanske komisije Vijeća Europe na engleskom i francuskom jeziku, a te su odluke sadržane i u europskoj bazi podataka CODICES. ${ }^{50}$

45 Ustavni sud, naime, prema samostalnom izboru sudaca može izdavati zbirke odluka, rješenja i izvješća za što se sredstva osiguravaju u državnom proračunu, a u slučaju da se zbirke pripremaju u okviru nekog stručnog projekta Ustavnog suda sredstva se mogu osigurati i iz sredstava iz kojih se financira takav projekt, sukladno članku 59. Poslovnika. Spomenuti „Izbor odluka Ustavnog suda Republike Hrvatske” unakrsno je strukturiran tako da s jedne strane obuhvaća normativu Ustava, Ustavnog zakona i ostalih ustavnopravnih izvora, a s druge strane to čini u duhu konstitucionalizma našeg pravnog poretka, prema najvažnijim granama prava. Metodološki je koncipiran na način da su najprije navedene odluke i rješenja doneseni u postupcima apstraktne ustavnosudske kontrole, a zatim odluke i rješenja doneseni u drugim ustavnosudskim postupcima. U svakom slučaju publiciraju se odluke koje su objavljene u Narodnim novinama te odluke koje su objavljene na službenim internetskim stranicama Ustavnog suda, a značajne su zbog određenih razloga, primjerice zbog načelnih pravnih stajališta Ustavnog suda.

46 Predsjednik Ustavnog suda odlučuje o potrebi objave službenog priopćenja Ustavnog suda o pojedinoj odluci, rješenju i izvješću ili o tijeku ustavnosudskog postupka koji još nije okončan, odnosno o određenom događanju u Ustavnom sudu ili o pitanju vezanom za položaj Ustavnog suda ili sudaca Ustavnog suda od šireg značaja za javnost. Iako je člankom 60. Poslovnika propisana takva mogućnost djelovanja Ustavnog suda, u praksi se ona često ne koristi.

47 Održavanje konferencija za tisak i druga sredstva javnog priopćavanja nije uobičajeni način javnosti djelovanja Ustavnog suda. Štoviše, konferencije za medije iznimno su rijetke pa smatramo da bi taj način komunikacije s javnošću Ustavni sud trebao mnogo više koristiti.

48 Ustavnosudski akti objavljeni u Narodnim novinama objavljuju se i na internetskim stranicama Ustavnog suda, dok se oni akti koji nisu objavljeni u Narodnim novinama objavljuju ukoliko to odluči sjednica, odnosno nadležno vijeće Ustavnog suda. O tome v. članke 55.a i 55.b Poslovnika.

49 Skreće se pozornost da su i preslike odluka, rješenja i izvješća koji nisu objavljeni u Narodnim novinama, a ne nalaze se ni na internetskoj stranici Ustavnog suda, dostupne svima ne temelju pisanog zahtjeva Ustavnom sudu, sukladno člancima 57. i 58. Poslovnika.

50 O javnosti djelovanja Ustavnog suda usp. Šarin, „Položaj ...“, op. cit. u bilj. 23, str. 1406-1407. 


\subsection{Problemi u praćenju rada Ustavnog suda Republike Hrvatske}

Iako Ustavni sud godišnje donese nekoliko odluka koje prelaze okvire pojedinačnih slučajeva i predstavljaju značajne pomake u razvoju hrvatskog ustavnog sudovanja te stoga imaju posebno značenje ne samo za Ustavni sud, već i za sva tijela državne i javne vlasti, jer su u njima sadržana načelna stajališta Ustavnog suda i razrada pojedinih ustavnih instituta, najviše medijske i opće pozornosti privlače slučajevi aktualnih i bivših političara kada je riječ o ustavnim tužbama, ${ }^{51}$ odnosno odluke i rješenja Ustavnog suda u postupcima ocjene suglasnosti s Ustavom onih zakona kod kojih je zainteresirana javnost već unaprijed „odlučila” kako bi Ustavni sud trebao postupiti.

U tom smislu i tijekom protekle (2015.) godine najviše medijske pozornosti izazvale su odluke Ustavnog suda u postupcima pokrenutima ustavnim tužbama opće poznatih podnositelja. Riječ je o odlukama brojeva U-III-4150/2010 od 12. siječnja 2015., ${ }^{52}$ U-III-4149/2014 od 29. srpnja $2015 .{ }^{53}$ i U-III-1451/2015 od 9. travnja 2015. ${ }^{54}$ Veliku pozornost javnosti privuklo je i rješenje Ustavnog suda broj: U-I-3101/2014 od 12. siječnja 2015. doneseno u povodu većeg broja prijedloga za pokretanje postupka za ocjenu suglasnosti s Ustavom Obiteljskog zakona. ${ }^{55}$

51 V. primjerice „Ustavni sud i kapitalci” (Glas Grada od 31. srpnja 2015.).

52 Naime, Ustavni sud je u odluci broj: U-III-4150/2010 od 12. siječnja 2015. (Narodne novine broj 6/15. i www.usud.hr) u postupku pokrenutom većim brojem ustavnih tužbi, od kojih je jednu podnio Branimir Glavaš, razmatrao ustavnopravni aspekt oružanog sukoba na području Republike Hrvatske 1991. godine te odnos Vrhovnog suda i Ustavnog suda u primjeni konvencijskog prava.

53 U konkretnom slučaju Ustavni sud je odlukom broj: U-III-4149/2014 od 29. srpnja 2015. (Narodne novine broj 89/15. i www.usud.hr) ukinuo presude Vrhovnog suda i Županijskog suda u Zagrebu u postupku koji je ustavnom tužbom pokrenuo Ivo Sanader (slučajevi Hypo i INA-MOL). Između ostalog, Ustavni sud utvrdio je da se, uvažavajući zahtjev vladavine prava, države ne smiju retroaktivno miješati u slučajeve u kojima je prije nastupila zastara kaznenog progona, te da je novi stavak 4. članka 31. Ustava otvorio, i to s djelovanjem pro futuro, vremenski neograničene mogućnosti kaznenog progona počinitelja kaznenih djela, u smislu članka 31. stavka 1. Ustava i nakon što isteknu rokovi za zastaru njihovog kaznenog progona, pod uvjetom da za ta djela na dan stupanja na snagu Promjene Ustava Republike Hrvatske (16. lipnja 2010.) nije nastupila zastara i da ona imaju zakonska obilježja propisana člankom 7. stavkom 1. Zakona o nezastarijevanju kaznenih djela ratnog profiterstva i kaznenih djela iz procesa pretvorbe i privatizacije iz 2011. (Narodne novine broj 57/11.). V. bilj. 60 i 61.

54 Ustavni sud je odlukom broj: U-III-1451/2015 od 9. travnja 2015. (Narodne novine broj 44/15. i www.usud.hr) ukinuo rješenja Županijskog suda u Zagrebu i rješenje suca istrage Županijskog suda u Zagrebu u postupku koji je ustavnom tužbom pokrenuo Milan Bandić koji se od 10. ožujka 2015. nalazio u istražnom zatvoru u trajanju od mjesec dana, to jest do 10. travnja 2015. V. bilj. 58.

55 Naime, Ustavni sud je rješenjem broj: U-I-3101/2014 od 12. siječnja 2015. (Narodne novine broj 5/15. i www.usud.hr), do donošenja konačne odluke, privremeno obustavio izvršenje svih pojedinačnih akata i radnji koje su se poduzimale na osnovi osporenog Obiteljskog zakona (Narodne novine broj 75/14.) te na temelju članka 31. stavka 5. Ustavnog zakona utvrdio da se, do donošenja konačne odluke, primjenjuje prethodno važeći Obiteljski zakon (Narodne novine broj 116/03., 17/04., 136/04., 107/07., 57/11., 61/11. i 25/13.). Ustavni sud suspendirao je primjenu osporenog Obiteljskog zakona, procijenivši da bi njegovom daljnjom primjenom mogle nastupiti teške i nepopravljive posljedice. 
Dr. sc. Duška Šarin: Javna narav i javna kontrola djelovanja Ustavnog suda Republike Hrvatske Zbornik radova Pravnog fakulteta u Splitu, god. 53, 4/2016., str. 923.-946.

U povodu javnih komentara dviju od tih odluka Ustavnog suda (ustavna tužba Branimira Glavaša, ${ }^{56}$ ocjena ustavnosti Obiteljskog zakona ${ }^{57}$ ), čak je pisanom Izjavom reagiralo i Predsjedništvo i Znanstveno vijeće Akademije pravnih znanosti Hrvatske: „Potaknuti neuobičajeno brojnim i različitim, a najčešće proizvoljnim i nedovoljno i/ili pogrešno argumentiranim stajalištima i izjavama sudionika, pa i predstavnika izvršne vlasti i pravne struke, u raspravama u sredstvima javnog priopćavanja ... smatraju neprihvatljivim i štetnim izjave koje su već neko vrijeme prisutne u hrvatskom javnom prostoru ... u kojima se naglašavaju i ponavljaju ocjene o , skandaloznosti', , političkoj uvjetovanosti', , isključivo političkim razlozima koji su diktirali tu odluku', ,neustavnosti', , protuustavnosti' donesenih odluka, stvaranju ,pravnog kaosa' i , pravnog nereda', , ustavnosudskom puču u hrvatskom pravnom sustavu' te drugim za javnu raspravu, i za citiranje u ovoj Izjavi, neprimjerenim i neutemeljenim ocjenama, Ustavni sud neargumentirano diskvalificira, dovode se u pitanje njegove ustavne ovlasti i izražavaju sumnje u stručnost i čast sudaca tog suda koji , svi imaju politički dres'. Stvaranjem i podržavanjem takvih negativnih predodžbi o Ustavnom sudu i njegovom djelovanju, provocira se u javnosti nepovjerenje u pravnu sigurnost i vladavinu prava u Republici Hrvatskoj. Time se otežava normalno funkcioniranje Ustavnog suda u ostvarenju njegove zaštitne i garantivne funkcije vladavine prava i zaštiti temeljnih ljudskih prava u skladu s Ustavom Republike Hrvatske". ${ }^{58}$

Mada se javnost djelovanja Ustavnog suda očituje na razne, prethodno razložene načine, osnovni problemi s praćenjem njegovog rada od strane zainteresirane javnosti odnose se na:

56 Primjerice: „Ustavni sud poigrao se Glavašem i cijelim sudstvom” (Večernji list od 14. siječnja 2015.), „Nakon 4,5 godine zastoja odluka o Glavašu donesena u četiri dana” (Jutarnji list, večernje izdanje od 14. siječnja 2015.), „Ustavni sud očito je jako taktizirao” (Jutarnji list, večernje izdanje od 14. siječnja 2015.).

57 Primjerice: „Drama zbog pada Obiteljskog zakona” (Jutarnji list od 14. siječnja 2015.), „Kaos nakon suspenzije važnog akta: oko šest stotina razvoda i ostalih postupaka u blokadi" (Glas Istre od 14. siječnja 2015.), „Atak na Sabor i Vladu” (Slobodna Dalmacija od 14. siječnja 2015.), „Razvedeni i posvojeni ostali bez izborene pravne zaštite" (Glas Slavonije od 14. siječnja 2015.).

58 Stoga su Predsjedništvo i Znanstveno vijeće Akademije pravnih znanosti Hrvatske pozvali sve dužnosnike u tijelima državne i javne vlasti i sve građane Republike Hrvatske na dužno poštovanje institucije Ustavnog suda i provođenje njegovih odluka. V. Izjavu Predsjedništva i Znanstvenog vijeća Akademije pravnih znanosti Hrvatske povodom donošenja odluke Ustavnog suda Republike Hrvatske U-III-4150/2010 i rješenja Ustavnog suda Republike Hrvatske U-I-3101/2014 od 12. siječnja 2015. godine, Zagreb, 22. siječnja 2015., https://www.pravo.unizg.hr/apzh/priopcenja?@=6v19\#news_11054, pristupljeno 9. svibnja 2016. 
Dr. sc. Duška Šarin: Javna narav i javna kontrola djelovanja Ustavnog suda Republike Hrvatske Zbornik radova Pravnog fakulteta u Splitu, god. 53, 4/2016., str. 923.-946.

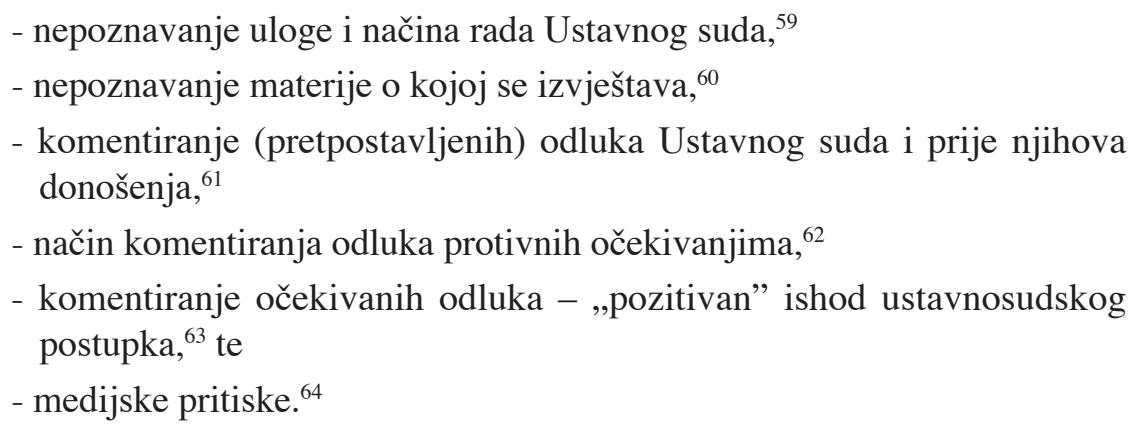

59 Vrlo često se kritički komentiraju odluke Ustavnog suda, a da se uopće ne poznaju ni njegove nadležnosti ni način rada, odnosno općenito ustavnopravni položaj Ustavnog suda. Primjerice: „Ustavni sud ne može rušiti jednoglasne odluke Sabora” (7 Dnevno od 16. listopada 2015.), „Ustavni sud svojom politikanskom odlukom zabranio sudovanje protiv Ive Josipovića” (Hrvatski tjednik od 21. svibnja 2015.), „O Bandiću preko noći, o mladima godinama” (Auto start od 1. svibnja 2015.), „Ako tužba ima manu, ustavni suci je ni ne pogledaju" (Slobodna Dalmacija od 26. svibnja 2015).

${ }^{60}$ Dobar primjer izvještavanja o potpuno nepoznatoj materiji jest kritički osvrt na odluku Ustavnog suda broj: U-I-5735/2014 i dr. od 12. kolovoza 2014. (Narodne novine broj 103/14. i www.usud.hr), donesenoj u postupku u povodu ocjene suglasnosti zakona i drugog propisa s Ustavom, u kojoj je Ustavni sud ukinuo i točku II. stavak 1. Vladine Odluke o korištenju rezidencijalnih objekata u vlasništvu Republike Hrvatske od 26. srpnja 2012., zbog nesuglasnosti s člankom 4. Ustava i temeljnim ustrojstvom državne vlasti te ustavnog sudstva. Naime, predmetnom odlukom Vlade objekte posebne namjene - rezidencijalne objekte u vlasništvu Republike Hrvatske mogli su koristiti samo: predsjednik Republike Hrvatske, predsjednik Hrvatskog sabora i predsjednik Vlade, a ne, kako je to prethodno bilo određeno, i predsjednik Vrhovnog suda te predsjednik Ustavnog suda. Dakle, prethodno je bila riječ samo o predsjedniku Ustavnog suda, a ne i o sucima Ustavnog suda, kako se izvještavalo: „,To je neustavno! - Ustavni sud poništio odluku koja ustavnim sucima brani odmor na Brijunima" (Jutarnji list od 16. kolovoza 2014.).

${ }^{61}$ Jedan od većih problema u praćenju rada Ustavnog suda jest komentiranje (pretpostavljenih) odluka Ustavnog suda i prije njihova donošenja. Dakle, radi se u potpunim špekulacijama, a na stanovit način i pritiscima. Primjerice: „Ustavni sud ukida presudu Sanaderu za INA - MOL i ratno profiterstvo?” (Glas Slavonije od 15. srpnja 2015.), „Obrat u režiji Ustavnog suda” (Nacional od 25. svibnja 2015.).

${ }^{62}$ Negativni komentari odluka protivnih očekivanjima šire javnosti uglavnom se svode na paušalne i proizvoljne ocjene eventualnih posljedica koje bi mogle nastupiti zbog tih odluka, a komentari ponekad idu sve do preispitivanja potrebe za Ustavnim sudom. Primjerice: „Ustavni sud po diktatu Vlade suzbija direktnu demokraciju” (24 sata od 22. travnja 2015.), „Ustavni sud abolirao ratno profiterstvo i osporio Sabor” (Glas Istre od 29. srpnja 2015.), „Odluka Ustavnog suda zaustavit će sve postupke zbog ratnog profiterstva” (Jutarnji list, večernje izdanje od 29. srpnja 2015.), „Posljednji čavao u lijes neposredne demokracije” (Školske novine od 14. travnja 2015.), ,Treba li nam uopće ovakav Ustavni sud?” (24 sata, večernje izdanje od 29. travnja 2015.), „Rušimo Ustavni sud” (Slobodna Dalmacija od 5. studenoga 2015.), „Ustavni sud je atavizam i treba ga ukinuti” (Globus od 27. svibnja 2016.).

63 Naime, problemi u praćenju rada postoje čak i u predmetima u kojima Ustavni sud donese odluke koje su u skladu s očekivanjima javnosti, jer tada je za njih obično zaslužan netko drugi: „Ograničenju od 80 kw nije presudio Ustavni sud, nego Auto klub" (Auto klub od 22. svibnja 2015.).

${ }^{64}$ Medijski pritisci odnose se na rokove do kojih bi odluke trebale biti donesene, sugeriranje „ispravnih” odluka, isticanje štetnih posljedica ,pogrešnih” odluka, pa sve do određenih „prijetnji”: „Ustavni sud odlučit će o švicarcima do 14. studenog” (Bjelovarac od 5. studenoga 2015.), „Ustavni sud mora pokazati odgovornost prema svome narodu” (Hrvatski tjednik od 12. ožujka 2015.), "Referendum ruši pelješki most” (Slobodna Dalmacija od 28. veljače 2015.), „Što ako Sanadera oslobode?” (Jutarnji list od 27. lipnja 2015.), „Ako ne bude referenduma, ubojito ćemo odgovoriti” (Danas.hr, 20. listopada 2010.). 
Najbolja ilustracija, koja sublimira navedeno, odnosi se na komentar rješenja Ustavnog suda broj: U-IP-3820/2009 od 17. studenoga 2009. ${ }^{65}$ donesenog u prethodno spomenutom postupku ustavnosti Zakona o posebnom porezu na plaće, mirovine i druge primitke, ${ }^{66}$ tzv. „kriznom porezu”: „Masovno krsteći krizni porez haračem javnost izražava svoj vrijednosni i emocionalni stav. Odluka Ustavnog suda da ga proglasi ustavnim neće promijeniti odnos prema tom poreznom nametu. Može promijeniti samo odnos prema Ustavnom sudu. ${ }^{" 67}$

Razlozi navedenih problema mogu biti razni, no dva su zasigurno najbitnija. S jedne strane, Ustavni sud je, s obzirom na svoju nadležnost koja ponekad uključuje odlučivanje i o materiji koja zanima i utječe na sve građane, u mnogo većoj mjeri i s mnogo više intenziteta izložen javnom mišljenju od prethodno spomenutih redovnih i specijaliziranih sudova, uključujući i Vrhovni sud. S druge strane, ustavnopravna osnova za djelovanje medija i njihov status u javnom prostoru sadržani su u jamstvu slobode mišljenja odnosno izražavanja misli kroz slobodu tiska i drugih sredstava priopćavanja. Naime, novinari imaju pravo na slobodu izvještavanja i pristupa informacijama koje posjeduju tijela javne vlasti, dakle i pravo na slobodu izvještavanja o radu Ustavnog suda. ${ }^{68}$ No, iako su zahtjevi koji se postavljaju pred medije veliki i složeni jer je materija kojom se Ustavni sud bavi vrlo obimna, a djelovanje njegovih odluka sveobuhvatno i dalekosežno, gotovo da nema tiskanih i elektronskih medija koji se sustavno bave značenjem i ulogom ustavnog sudovanja odnosno Ustavnim sudom na način koji bi bio primjeren široj javnosti.

Na kraju, treba reći da iako ima i mnoštvo pozitivnih primjera glede međusobnog odnosa Ustavnog suda i medija odnosno javnosti uopće, ${ }^{69}$ ovdje se prvenstveno željelo ukazati na postojeće probleme kako bi se oni u što skorije vrijeme mogli riješiti.

${ }^{65}$ V. rješenje Ustavnog suda broj: U-IP-3820/2009 od 17. studenoga 2009. (Narodne novine broj 143/09. i www.usud.hr).

${ }^{66}$ V. bilj. br. 40.

67 „Hrvati umorni od voljenih vođa” (Jutarnji list od 18. studenoga 2009.)

${ }^{68}$ Ovdje valja napomenuti da je sloboda mišljenja i izražavanja misli, zajamčena člankom 38 . Ustava, kao uvjet za ostvarivanje drugih ljudskih prava i temeljnih sloboda, jedan od glavnih oslonaca za izgradnju pluralističkog i demokratskog društva vladavine prava i Ustava, odnosno ustavne države kakvoj težimo. O tome v. Arlović, M.: „Pravo na slobodu izražavanja misli (ustavnopravni okvir i ustavnosudska praksa u Republici Hrvatskoj“, Zbornik radova Pravnog fakulteta u Splitu, Split, 2016., god. 53, br. 2, str. 377-411.

69 To pokazuju upravo izjave istih onih koji su ranije negativno komentirali pojedine odluke Ustavnog suda: „Hrvatski sabor može izglasati bilo kakav zakon, ali onda taj zakon mora proći i ustavni test" (Slobodna Dalmacija od 22. srpnja 2015.). Isto tako i u jeku najžešće medijske kampanje u vezi s nekim najeksponiranijim ustavnosudskim predmetima bilo je i afirmativnih članaka glede rada Ustavnog suda: „Ustavni sud kvalitetno će odraditi slučaj Sanader bez obzira na pritiske” (Večernji list od 15. srpnja 2015.). 


\subsection{Moguća rješenja}

Premda se problemi u praćenju djelovanja Ustavnog suda od strane zainteresirane javnosti odnosno kritike njegovog rada i odluka u pravilu svode na optužbe za dnevnopolitičku instrumentalizaciju ili na preispitivanje integriteta sudaca, dosta je i slučajeva pogrešne interpretacije odluka Ustavnog suda zbog prethodno navedenih razloga. U svakom slučaju, moguća prevencija kritika djelovanja Ustavnog suda kao i moguća reakcija na neutemeljene i neargumentirane kritike bila bi:

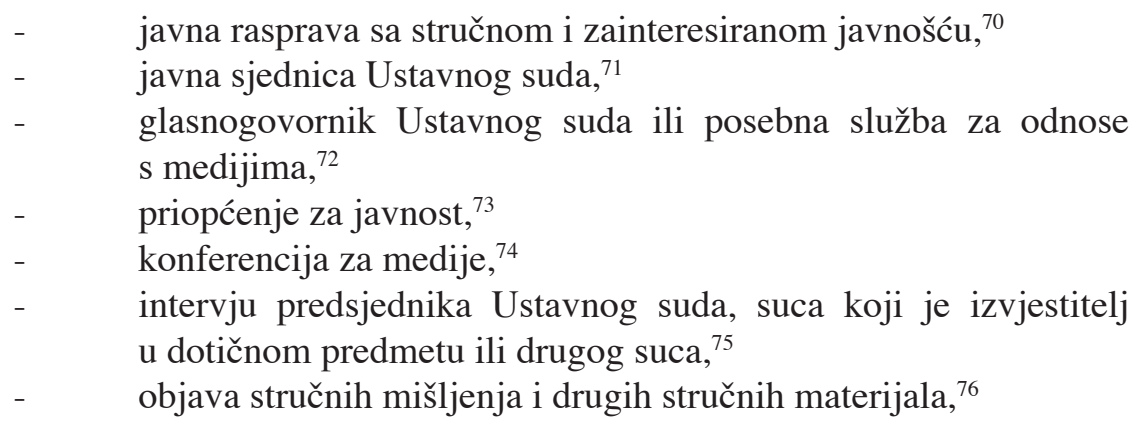

70 Češća organizacija javnih rasprava sa stručnom, a po potrebi i zainteresiranom javnošću zasigurno bi pridonijela većoj javnosti djelovanja Ustavnog suda, a pribavila bi se i potpuna stručna argumentacija o svim spornim pitanjima. Ustavni sud, naime, iznimno rijetko organizira javne rasprave te ih je bilo samo nekoliko u proteklih desetak godina. Spomenimo još da održavanje javne rasprave ne isključuje i mogućnost prethodnog održavanja savjetodavne rasprave, koja se, također, može održati u nazočnosti stručne javnosti te medija.

71 Sukladno prethodno navedenome, javnost djelovanja Ustavnog suda ostvaruje se nazočnošću predstavnika tiska i drugih sredstava javnog priopćavanja na sjednici Ustavnog suda. Međutim, sjednice Ustavnog suda u pravilu se održavaju bez nazočnosti medija. Primjerice, Ustavni sud tijekom 2015. godine te u prvih šest mjeseci 2016. godine nije održao nijednu javnu sjednicu.

72 Iako Ustavni sud nema posebnu osobu zaduženu za odnose s javnošću, smatramo da bi bilo svrsishodno što prije odrediti glasnogovornika Ustavnog suda. Hoće li to biti netko od sudaca, glavni tajnik Ustavnog suda, ustavnosudski savjetnik ili neka druga osoba specijalizirana za odnose s medijima, trebala bi odlučiti sjednica Ustavnog suda, dakle plenum od 13 sudaca. Smatramo da odluka plenuma ne bi bila potrebna glasnogovorniku za svako obraćanje javnosti već bi to radio u dogovoru s predsjednikom Ustavnog suda, a samo po potrebi i s ostalim sucima. Slična situacija bila bi i u slučaju da Ustavni sud oformi posebnu službu za odnose s medijima kao što to imaju pojedini ustavni sudovi te Europski sud. U svakom slučaju, sve to trebalo bi detaljno urediti Poslovnikom.

73 Jedno od mogućih rješenja navedenog problema jest i priopćenje za javnost od strane predsjednika Ustavnog suda kao čelnika institucije ili potencijalnog glasnogovornika odnosno službe za medije ukoliko bude oformljena.

74 Dobar način informiranja najšire javnosti su i konferencije za medije od strane istih onih koji bi bili ovlašteni davati priopćenja za javnost s tim da bi na konferenciji mogli biti nazočni svi suci Ustavnog suda, odnosno samo sudac koji je bio izvjestitelj u konkretnom predmetu.

75 Reakcija na kritike odnosno pogrešne interpretacije odluka Ustavnog suda moguća je i kroz intervju predsjednika Ustavnog suda ili intervju suca koji je bio izvjestitelj u konkretnom predmetu, ali i ostali suci mogli bi se u intervjuima očitovati o tome.

76 Kako bi se zainteresirana javnost što bolje informirala o razlozima koji su doveli do pojedine odluke Ustavnog suda koja je pobudila veliki interes, bilo bi poželjno da se u određenim predmetima objave stručna mišljenja te izrade i objave drugi stručni materijali. 
Dr. sc. Duška Šarin: Javna narav i javna kontrola djelovanja Ustavnog suda Republike Hrvatske Zbornik radova Pravnog fakulteta u Splitu, god. 53, 4/2016., str. 923.-946.

- $\quad$ zahtjev za objavu ispravka ili odgovora, ${ }^{77}$ te

- $\quad$ kombinacija mogućih rješenja. ${ }^{78}$

Ustavni sud, međutim, u pravilu službeno ne reagira na neopravdane kritike njegovih odluka. Premda je Ustavni sud u svojoj praksi, kao što je to prethodno prikazano, višekratno odlučivao o predmetima koji su u javnosti pobudili izuzetan interes i oštre kritike, reakcija Ustavnog suda je izostala. U pojedinim slučajevima je i tijekom samog postupka, dakle, prije donošenja odluke Ustavnog suda javno mišljenje bilo snažno izraženo te je provođena medijska kampanja. No, Ustavni je sud samo iznimno održavao konferencije za medije, ${ }^{79}$ te medijima slao priopćenja samo kad se radilo o netočnim navodima i pogrešnim tumačenjima odluka koja je doista trebalo ispraviti. ${ }^{80}$

Ipak, valja reći da su se, ponekad, predsjednica i suci Ustavnog suda na druge načine osvrnuli na takve kritike i po potrebi pojasnili razloge donošenja komentiranih odluka. Primjerice, davanjem intervjua, izjava medijima ili izlaganjem na okruglim stolovima odnosno raznim znanstvenim i stručnim savjetovanjima u zemlji i sl. ${ }^{81}$ Iako Ustavni sud posljednjih godina ima strateški plan kojem je opći cilj jačanje ustavnog sudovanja u Republici Hrvatskoj radi obrane Ustava kao vrhovne pravne norme i osiguranja djelotvorne zaštite ustavnih prava, a jedan od posebnih ciljeva je otvaranje Ustavnog suda javnosti i podizanje informiranosti građana o značenju i ulozi ustavnog sudovanja, između ostalog, javnim nastupima i konferencijama za tisak, prvenstveno je bila riječ o ad hoc reakcijama na kritike pojedinih odluka koje

77 Najzad, kao jedno od mogućih rješenja jest i zahtjev za objavu ispravka ili odgovora koji bi se trebao koristiti u situacijama kada je potrebno ispraviti netočne navode odnosno odgovoriti na iste.

78 Konačno, u pojedinim ekstremnim situacijama u kojima bi se uz pogrešnu interpretaciju odluka Ustavnog suda pogrešno interpretirala i njegova priopćenja ili izjave pojedinih sudaca potrebno je koristiti više od jedne navedene mogućnosti.

79 Primjerice, zbog velikog interesa javnosti i medijske kampanje u tijeku postupka za odlučivanje o tzv. „,kriznom porezu”, predsjednica Ustavnog suda održala je konferenciju za novinare još tijekom tog postupka, a održana je i savjetodavna javna rasprava.

${ }^{80}$ Naime, Ustavni sud je u svega nekoliko slučajeva reagirao priopćenjem za javnost odnosno traženjem ispravka objavljene informacije. Primjerice, tijekom 2015. godine, priopćenjem predsjednice Ustavnog suda u povodu odluke Ustavnog suda broj: U-I-1397/2015 od 24. rujna 2015. zbog izjava i komentara pojedinih zastupnika izrečenih za vrijeme zasjedanja Hrvatskog sabora 25. rujna 2015. Posljednje reakcije Ustavnog suda bile su 10. svibnja 2016., koja se odnosila na ispravak objavljenih netočnih informacija u vezi sa ,slučajem Sanader” (7 Dnevno od 6. svibnja 2016.), te 3. lipnja 2016. koja se odnosila na ispravak netočnog navoda u Dnevniku Nove TV od 2. lipnja 2016. u vezi s odlukom Ustavnog suda broj: U-I-1397/2015 od 24. rujna 2015.

81 Navedene mogućnosti najčešće je koristila predsjednica Ustavnog suda koja se redovito u svojim intervjuima osvrtala na neargumentirane i neutemeljene kritike javnosti vezane uz pojedine medijski vrlo eksponirane predmete. 
Dr. sc. Duška Šarin: Javna narav i javna kontrola djelovanja Ustavnog suda Republike Hrvatske Zbornik radova Pravnog fakulteta u Splitu, god. 53, 4/2016., str. 923.-946.

nisu bile rezultat posebno razrađene strategije odnosa Ustavnog suda s medijima i

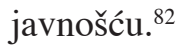

Međutim, iako se Ustavni sud nije u mogućnosti aktivno uključivati u političku ili medijsku raspravu već treba zauzeti neutralan stav, ipak može olakšati informiranje javnosti kroz precizno i ciljano plasirane informacije kako bi se po potrebi razjasnile njegove pojedine odluke. Naime, odlučujuće naznake o tome na koji način će u javnosti biti primljena odluka Ustavnog suda odnosno kako će se u društvu razvijati okvirne okolnosti za njezino provođenje mogu se prepoznati već u prvim izvještajima nakon objave odluke, a vrlo često, kao što je to prethodno prikazano, i za vrijeme trajanja ustavnosudskog postupka. Stoga je ovdje suradnja Ustavnog suda s medijima od posebnog značaja.

U skladu s tim, smatramo potrebnim da Ustavni sud preispita dosadašnju praksu i učini određene korake kako bi se unaprijed spriječile pretpostavljene negativne kritike i prije donošenja same odluke odnosno kako bi se ciljano informirala javnost i pojasnili razlozi donošenja odluke kao reakcija na negativne neutemeljene i vrlo često neargumentirane kritike nakon donošenja odluke. ${ }^{83}$ Naime, unatoč spomenutom strateškom planu, Ustavni sud trebao bi što prije izraditi i detaljan plan odnosno posebnu strategiju svog odnosa s medijima i javnošću općenito koja bi dala odgovore na postavljena pitanja odnosno ukazane probleme, a sve u cilju poboljšanja javne naravi i javne kontrole djelovanja Ustavnog suda.

Dosljedno tome, potrebno je preispitati i dosadašnju praksu Ustavnog suda glede održavanja javne rasprave koja je, kao što je spomenuto, simbolična, s istim ciljem da se što više direktno i dosljedno primijeni načelo javnosti. U tom smislu, ima mjesta, kako je to uvodno navedeno, i preispitivanju postojećih normativnih rješenja na način da se pitanje održavanja javne rasprave u postupku pred Ustavnim sudom izuzme iz diskrecijske ovlasti samog Ustavnog suda i najavljenim promjenama Ustavnog zakona, koje su neophodne i zbog drugih pitanja, ${ }^{84}$ konstituira i pobliže

82 Više o mogućoj reakciji ustavnih sudova na negativne kritike njihovih odluka, kao i o prethodnim iskustvima Ustavnog suda v. Antić, T.: „Reagiranje ustavnih sudova na negativne kritike njihovih odluka“, Pravni vjesnik, Pravni fakultet u Osijeku, Osijek, 2012., god. 28, br. 3-4, str. 47-64.

83 Mišljenja smo da bi pojedine odluke Ustavnog suda za koje se pretpostavlja da će biti predmet posebnog javnog interesa odmah nakon njihova donošenja trebalo na sažet $i$ jednostavan način objasniti i dostaviti medijima kako bi oni potpuno $i$ točno mogli informirati najširu javnost o razlozima kojima se Ustavni sud rukovodio pri donošenju odluke odnosno o pravnim stavovima Ustavnog suda na kojima se odluka temelji. Iako Ustavni sud sve češće sažetke određenih odluka objavljuje na svojoj internetskoj stranici, oni su preobimni da bi ih mediji mogli prenijeti u cijelosti, ali i prestručni. Naime, odluke Ustavnog suda, kao i ostalih ustavnih sudova, pisane su „pravničkim jezikom”, ili čak, prema nekim mišljenjima, ,kineskim pravničkim jezikom” pa stoga javnosti nisu u potpunosti razumljive. Usp. Hömig, op. cit. u bilj. 9, str. 14-15.

${ }^{84}$ U ovom trenutku najaktualnije pitanje posljedica je promjene Ustava iz 2010. godine kojim je članak 122. stavak 1. Ustava dopunjen na način da se mandat suca Ustavnog suda produžuje „,do stupanja na dužnost novog suca u slučaju da do njegova isteka novi sudac nije izabran ili nije stupio na dužnost..." Naime, ni Ustav ni Ustavni zakon ne odgovaraju na pitanje što je u situaciji kada je riječ o više sudaca. 
odredi obveza održavanja javne rasprave u određenoj vrsti ustavnosudskih postupaka.

\section{UMJESTO ZAKLJUČKA}

Analiza dana u ovom radu pokazuje da postoji prostor za poboljšanje javne naravi i javne kontrole djelovanja Ustavnog suda. S jedne strane, budući da je materija kojom se Ustavni sud bavi vrlo obimna i široka, a djelovanje njegovih odluka iznimno je snažno i dalekosežno, bitno je da se Ustavni sud i njegova jurisprudencija približe građanima kako bi javnost bila u mogućnosti prepoznati koristi ustavnog sudovanja za državu i društvo u cjelini. S druge strane, pluralističko društvo suvremene demokracije kojem težimo, utemeljeno, inter alia, i na bogatstvu različitosti, nije moguće ostvariti bez otvorene javne rasprave o svim segmentima djelovanja sve tri grane vlasti, dakle, zakonodavne, izvršne i sudbene, te Ustavnog suda kao „,̌etvrte vlasti”. Stoga, nijedna institucija javne vlasti, pa tako ni Ustavni sud, nije i ne smije biti izuzeta od preispitivanja i argumentirane analize djelovanja, a po potrebi i stručne i znanstveno utemeljene kritike. ${ }^{85}$

Štoviše, obavljanje javne dužnosti znači i preuzimanje obveze da se javnost izvijesti „pravodobno, potpuno, na odgovarajući i pristupačan način” o tome kako se ta dužnost vrši. Upravo mediji trebaju omogućiti javnosti da bude upoznata s poslovima javne vlasti i održavati interes javnosti za javne poslove, ali i braniti slobodu mišljenja i izražavanja, poticati vrijednosti tolerancije i pluralizma, te promicati etičnost i odgovornost u svim sferama društva ${ }^{86}$ Drugim riječima, mediji, kao svojevrsna kontrola javne vlasti, nezaobilazni su faktori u permanentnom procesu slobodnog i sveobuhvatnog formiranja javnog mišljenja i volje javnosti, te kao takvi uživaju i ustavna institucionalna jamstva u Republici Hrvatskoj. Naime, javno mišljenje koje se slobodno formira i koje je na najbolji način informirano, predstavlja onaj ključni sastojak bez kojeg nema funkcionalne i liberalne demokracije. Prema tome, uloga medija izuzetno je bitna, jer o njima, kao i posrednicima putem kojih javnost šalje svoje poruke, uvelike ovisi kakva će se javna rasprava voditi.

Konkretno, prema kojim kriterijima se pojedinim sucima ili sucu mandat produžuje, odnosno ne produžuje u situaciji kada nisu izabrani svi novi suci ili kada ne stupe na dužnost istog dana? Pored toga, Ustavnim zakonom trebalo bi riješiti i pitanje izbora odnosno reizbora ustavnih sudaca, financiranja (proračuna) Ustavnog suda i dr.

85 V. Izjavu ..., op. cit. u bilj. 57.

86 Usp. Kregar, J.: Pravojavnosti je reći, https://www.pravo.unizg.hr/_download/repository/Kregar_ Pravo_javnosti_je_reci\%5B1\%5D.doc., pristupljeno 9. svibnja 2016. 
Zbog toga je od velikog značaja odnos medija i uopće najšire javnosti prema radu i odlukama Ustavnog suda, osobito kad je riječ o onim odlukama koje na bilo kakav način utječu na prava i obveze velikog broja građana, a koje su takve naravi i imaju takve učinke da u određenim okolnostima mogu doživjeti kritike javnosti. Dakako, kritika od strane medija i javnosti općenito nužna je u demokratskom društvu utemeljenom na vladavini prava pri čemu bi bilo poželjno da Ustavni sud prakticira aktivniju komunikaciju i suradnju s medijima, kako to, primjerice, čini njemački Savezni ustavni sud ili Europski sud, jer smatramo da je iznimno važno na kritike odgovoriti argumentima. Naime, na koji će način javnost percipirati odluku Ustavnog suda suprotnu očekivanjima, ne ovisi samo o kvaliteti njezina obrazloženja, već u znatnoj mjeri ovisi i o načinu izvještavanja medija, kao i o odgovarajućoj reakciji Ustavnog suda.

Stoga bi bilo svrsishodno da Ustavni sud, radi pravovremenog, potpunog i odgovarajućeg informiranja javnosti, izradi, uz postojeći strateški plan ili unutar njega, i poseban plan odnosno strategiju odnosa s medijima i javnošću uopće, koji bi odgovorili na pitanje: na koje još načine približiti širokoj javnosti djelovanje Ustavnog suda te kako spriječiti odnosno reagirati na neutemeljene i neargumentirane kritike. U svakom slučaju, adekvatan plan ili strategija te njihova pravilna implementacija pridonijeli bi stvaranju bolje medijske slike o ustavnom sudovanju i njegovom značenju i ulozi u društvu, a time i rastu odnosno održavanju autoriteta i ugleda Ustavnog suda kao čuvara Ustava. ${ }^{87}$ Tome bi pridonijelo i preispitivanje postojećih normativnih rješenja, odnosno u radu predložene promjene.

\section{Literatura}

Antić, T.: „Reagiranje ustavnih sudova na negativne kritike njihovih odluka“, Pravni vjesnik, Pravni fakultet u Osijeku, Osijek, 2012., god. 28, br. 3-4, str. 47-64.

Arlović, M.: „Pravo na slobodu izražavanja misli (ustavnopravni okvir i ustavnosudska praksa u Republici Hrvatskoj)“, Zbornik radova Pravnog fakulteta u Splitu, Split, 2016., god. 53, br. 2, str. 377-411.

Bačić, A.: „Ustav Republike Hrvatske i problematika podjele vlasti“, Zakonitost, Zagreb, 1991., Vol. 45, br. 2, str. 153-163.

Bačić, A.: „Konstitucionalizam i podjela vlasti u „reaktivnim” ustavima postkomunističkog razdoblja“, Politička misao, Zagreb, 1992., Vol. XXIX., No. 1, str. 4355 .

87 O takvom pristupu v. Antić, „Reagiranje...“, op. cit. u bilj. 82. 
Dr. sc. Duška Šarin: Javna narav i javna kontrola djelovanja Ustavnog suda Republike Hrvatske Zbornik radova Pravnog fakulteta u Splitu, god. 53, 4/2016., str. 923.-946.

Bačić, P.: „Suvremeni konstitucionalizam i „nova” dioba vlasti“, Zbornik radova Pravnog fakulteta u Splitu, Split, 2009, god. 46, br. 4, str. 747-779.

Barić, S.: „Organski zakoni i Ustavni sud Republike Hrvatske u usporednopravnoj perspektivi“, u: Liber amicorum in honorem Jadranko Crnić (1928. - 2008.), Novi informator, Zagreb, 2009., str. 251-283.

Crnić, I.: Neovisnost sudstva, Vrhovni sud Republike Hrvatske,

http://www.vsrh.hr/easyweb.asp?pcpid=698

Crnić, J., Filipović, N. (ur.): Ustavni sud u zaštiti ljudskih prava: interpretativna uloga Ustavnog suda, Biblioteka Pravo 24, Zagreb, Hrvatski pravni centar, Organizator, Hrvatski institut za ljudska prava Novi Vinodolski, Hans Seidel Stiftung, Deutsche Stiftung für internationale rechtliche Zusammenarbeit e.V., 2000.

Dika, M.: „Načelo javnosti u parničnom postupku - prilog pokušajima opravdanja i reafirmacije instituta“, Zbornik Pravnog fakulteta Sveučilišta u Rijeci, Rijeka, 2008., god. 29 , br. 1, str. 1-26.

Draškić, M.: Javnost sednica Ustavnog suda Srbije - kako je bilo i kako je sada?, str. 1-11, Fondacija Centar za javno pravo,

http://www.fcjp.ba/templates/ja_avian_ii_d/images/green/Marija_Draskic2.pdf.

Geissler, T.: „Predgovor“, Izbor odluka Ustavnog suda Savezne Republike Njemačke, Zaklada Konrad Adenauer, Zelina, 2015., str. 11-12.

Goldsworthy, J.: Constitutional Interpretation, The Oxford Handbook of Comparative Constitutional Law, 2013., str. 689-715.

Häberle, P.: Role and Impact of Constitutional Courts in a Comparative Perspective, The Future of the European Judical System in a Comparative Perspective, Nomos, BadenBaden, 2006.

Harutyunyan, G., Mavčič, A.: Constitutional Review and its Development in the Modern World (A Comparative Constitutional Analysis), Electronic Book, YerevanLjubljana, 1999., Ustavni sud Republike Armenije, www.concourt.am/armenian/library/ cclibrary/1999/009.doc.

Hömig, D.: „Ustavni sudovi i mediji u Saveznoj Republici Njemačkoj“, str. 1-16, referat za konferenciju Ustavni sud i mediji, Republika Srbija, Kladovo, 3. do 5. rujna 2015. (arhiva Ustavnog suda Republike Hrvatske).

Kregar, J.: Pravo javnosti je reći,

https://www.pravo.unizg.hr/_download/repository/Kregar_Pravo_javnosti_je_ reci\%5B1\%5D.doc.

Omejec, J.: „Novi europski tranzicijski ustavi i transformativna uloga ustavnih sudova“, u: Dvadeseta obljetnica Ustava Republike Hrvatske, HAZU, Zagreb, 2011., str. 61-85. 
Omejec, J.: „Jurisprudencija njemačkog Saveznog ustavnog suda i hrvatsko ustavno sudstvo“, Izbor odluka Ustavnog suda Savezne Republike Njemačke, Zaklada Konrad Adenauer, Zelina, 2015., str. 15-26.

Salomon, N.: „Odnosi s medijima Europskog suda za ljudska prava“, str. 1-9, referat za konferenciju Ustavni sud i mediji, Republika Srbija, Kladovo, 3. do 5. rujna 2015. (arhiva Ustavnog suda Republike Hrvatske).

Slijepčević, D. B.: Javnost rada u praksi Ustavnog suda Srbije, str. 1-13, Fondacija Centar za javno pravo,

http://www.fcjp.ba/templates/ja_avian_ii_d/images/green/Dragisa_B_Slijepcevic.pdf

Sokol, S.: „Načelo diobe ili ograničenja vlasti“, Politička misao, Zagreb, 1992., Vol. XXIX, No. 1, str. 3-18.

Sokol, S.: „Odnos Ustavnog suda i tijela sudbene vlasti“, Zbornik Pravnog fakulteta u Zagrebu, Zagreb, 2000., Vol. 50, br. 1-2, str. 55-64.

Šarin, D.: „Načelo diobe vlasti i njegova primjena u hrvatskom ustavnom uređenju“, Vladavina prava, Zagreb, 1999., god. III., br. 6, str. 157-170.

Šarin, D.: „Položaj Ustavnog suda Republike Hrvatske s motrišta diobe vlasti i ustavne garancije njegove neovisnosti“", Zbornik Pravnog fakulteta u Zagrebu, Zagreb, 2012., Vol. 62, br. 5-6, str. 1379-1412.

Šarin, D.: „Ustavni sud Republike Hrvatske kao institucionalni zaštitnik ljudskih prava i temeljnih sloboda“, Zbornik radova Pravnog fakulteta u Splitu, Split, 2015., god. 52, br. 3, str. 755-784.

Zierlein, K. G.: „Uloga ustavnih sudova pri interpretaciji pravnih normi““, u: Ustavni sud u zaštiti ljudskih prava: interpretativna uloga Ustavnog suda, Organizator, Zagreb, 2000., str. 327-346.

\section{Propisi}

1. Ustav Republike Hrvatske (Narodne novine broj 56/90., 135/97., 113/00., 28/01., 76/10. i 5/14.)

2. Ustavni zakon o Ustavnom sudu Republike Hrvatske (Narodne novine broj 99/99. i 29/02.)

3. Poslovnik Ustavnog suda Republike Hrvatske (Narodne novine broj 181/03., 16/06., 30/08., 123/09., 63/10., 121/10., 19/13., 37/14. i 2/15.)

4. Zakon o Ustavnom sudu (Službeni glasnik Republike Srbije broj 109/07., 99/11., 18/13., 40/15. i 103/15.)

5. Poslovnik o radu Ustavnog suda (Službeni glasnik Republike Srbije broj 103/13.) 
Dr. sc. Duška Šarin: Javna narav i javna kontrola djelovanja Ustavnog suda Republike Hrvatske Zbornik radova Pravnog fakulteta u Splitu, god. 53, 4/2016., str. 923.-946.

\section{Poslovnik Suda (www.echr.coe.int)}

Izjava Predsjedništva i Znanstvenog vijeća Akademije pravnih znanosti Hrvatske povodom donošenja odluke Ustavnog suda Republike Hrvatske U-III-4150/2010 i rješenja Ustavnog suda Republike Hrvatske U-I-3101/2014 od 12. siječnja 2015. godine, Zagreb, 22. siječnja 2015., https://www.pravo.unizg.hr/apzh/priopcenja?@=6vl9\#news_11054

Odluke Ustavnog suda Republike Hrvatske navedene u radu.

\section{PUBLIC NATURE AND PUBLIC CONTROL OF THE REPUBLIC OF CROATIA'S CONSTITUTIONAL COURT ACTIVITY-}

It is not possible to achieve a democratic society without open public debate on all segments of activity of legislative, executive and judicial powers including the Constitutional Court of the Republic of Croatia. Therefore, the public nature and public control of its activity is of great significance and related is the relationship between the media and the wider public towards the work of the Constitutional Court. This paper attempts to point out in general the task of constitutional judges today and, in particular, deal with the public nature of activities through comparative analysis of certain constitutional courts and the European Court of Human Rights. The public nature of Constitutional Court activity is analysed in more detail through its constitutional legal position and the way it achieves public activity. Problems in following the work of the Constitutional Court on the part of the interested public are pointed out and possible solutions are considered. Analysis of a working day shows that there is room for improvement in the public activity of the Constitutional Court de lege lata and de lege ferenda.

Key words: public nature, public activity, Constitutional Court, the media 